\title{
Anti-Tuberculosis Drug Resistant Rates in Mycobacterium tuberculosis Isolated from Respiratory Specimens: A Multicenter Study in Korea
}

\author{
Jayoung Kim', Yeon-Joon Park', Nam Yong Lee ${ }^{2}$, Chulhun L. Chang ${ }^{3}$, Miae Lee ${ }^{4}$, Jong Hee Shin ${ }^{5}$ \\ ${ }^{1}$ Department of Laboratory Medicine, College of Medicine, The Catholic University of Korea, Seoul, \\ ${ }^{2}$ Department of Laboratory Medicine, Samsung Medical Center, Sungkyunkwan University, School of Medicine, \\ Seoul, ${ }^{3}$ Department of Laboratory Medicine, Pusan National University Yangsan Hospital, Yangsan, \\ ${ }^{4}$ Department of Laboratory Medicine, Ewha Womans University Mokdong Hospital, Seoul, ${ }^{5}$ Department of \\ Laboratory Medicine, Chonnam National University Medical School, Gwangju, Korea
}

Background: We analyzed the prevalence of anti-tuberculosis drug resistance in Mycobacterium tuberculosis isolates from respiratory specimens of patients with newly diagnosed and previously treated tuberculosis.

Methods: From February 2010 to July 2010, a total of $542 \mathrm{M}$. tuberculosis clinical isolates were collected from pulmonary tuberculosis patients in six university hospitals distributed throughout Korea. We analyzed the results of anti-tuberculosis drug resistance tests according to treatment history and geographic location. Results: Among the 542 isolates, 473 (87.3\%) were from newly diagnosed cases and $69(12.7 \%)$ were from previously treated cases. The rates of multi-drug resistance (MDR), fluoroquinolone (ofloxacin, levofloxacin, and moxifloxacin) resistance, and extensive drug resistance (XDR) were $3.8 \%, 1.1-1.5 \%$, and $0 \%$, respectively, in new cases, and $21.7 \%, 13.0-17.4 \%$, and $4.3 \%$, respectively, in previously treated cases. In the previously treated cases, the proportions of XDR-TB in MDR-TB were $20 \%(3 / 15)$. The resistance rates were variable according to geographic location.

Conclusion: As the anti-tuberculosis drug resistance rates are much higher in newly diagnosed cases than in previously treated patients, efforts should be made to ensure that tuberculosis treatment is successful. In addition, before the selection of an anti-tuberculosis drug treatment for previously treated patients, the susceptibility test results, including to fluoroquinolone, should be verified. (Ann Clin Microbiol 2013;16:1-7)

Key Words: Anti-tuberculosis drug resistant rates, Extensive drug resistance, Multi-drug resistance, Mycobacterium tuberculosis

\section{서 론}

약제내성결핵의 실태와 추이를 파악하는 것은 국가의 결핵 관리 사업의 성과를 평가하는데 있어서 가장 중요한 역학적 지 표 중의 하나로써, 항결핵제 감수성 결과를 토대로 다제내성결 핵(multi-drug resistant tuberculosis, MDR-TB)을 진단하고 적절 한 항결핵제를 선택하게 된다[1-3]. 약제내성 여부를 예측할 수 있는 인자로는 과거에 치료한 경력이 있거나 내성결핵 비율이 높은 지역에 거주한 환자이거나 MDR-TB 환자와 접촉한 과거 력이 있을 경우 등이 있다[2,4]. 그러나, 미국 Bloch 등[5]의 연 구에 따르면 약제내성결핵 환자의 $60 \%$ 는 특별한 위험 인자가 없는 것으로 보고하면서 따라서 모든 결핵환자에 대해 항결핵

Received 31 May, 2012, Revised 17 September, 2012

Accepted 17 September, 2012

Correspondence: Yeon-Joon Park, Department of Laboratory Medicine, The Catholic University of Korea, Seoul St. Mary's Hospital, 505, Banpo-dong, Seocho-gu, Seoul 137-701, Korea. (Tel) 82-2-22581640, (Fax) 82-2-2258-1719, (E-mail) yjpk@catholic.ac.kr
제 감수성 검사가 필요하다고 주장하였다. 이에 미국은 초치료 환자를 포함한 모든 결핵환자에서 항결핵제 감수성 검사를 시 행하도록 하고 있으며[2,4], 국내도 최근 질병관리본부 결핵 진 료지침에 의하면 항결핵제 감수성 시험은 모든 결핵환자의 첫 배양 분리 균주에 대해 실시하며 3개월 이상 치료에도 배양 양 성이거나 임상적으로 치료 실패가 의심되는 경우에는 다시 시 행하는 것을 권고하고 있다[6]. 그러나 아직까지 병원마다 또는 같은 병원이라도 주치의마다 항결핵제 감수성 검사를 의뢰하 는 관행이 서로 달라 시기별, 병원별로 혹은 지역별로 항결핵 제 내성률을 비교하기 어려운 실정이다[7].

현재까지 국내의 항결핵제 내성실태를 분석한 자료들을 보 면 결핵환자 중 주치의로부터 항결핵제 감수성 검사가 의뢰된 균주만을 대상으로 과거 치료 여부와 관계없이 항결핵제 내성 률을 보고하였거나[8-10], 결핵균으로 판명된 모든 균주들을 대상으로 과거 치료 여부에 따라 나누어 분석하더라도 일개 병 원 혹은 한 지역 병원들로 국한되어 시행되었거나[7,10,11], 전 
국 단위에서 시행된 연구더라도 보건소나 결핵전문 병, 의원에 등록된 환자만을 대상으로 분석된 보고였다[3].

이에 본 연구자들은 국내에서는 처음으로 전국에 분포한 6 개 대학병원의 호흡기 검체에서 검출된 모든 결핵균을 대상으로 초치료군과 재치료 환자군별로 나누어 항결핵제 내성률을 조 사하고 병원별, 지역별로 내성양상을 비교함으로써 결핵치료 및 관리를 위한 기초 자료를 제공하고자 하였다.

\section{대상 및 방법}

\section{1. 대상}

2010년 2월부터 7월 사이에 전국에 분포한 국내 6개 대학병 원(가톨릭대학교 서울성모병원, 성균관대학교 삼성서울병원, 이화여자대학교 목동병원, 가톨릭대학교 대전성모병원, 전남대 학교병원, 양산부산대학교병원)의 진단검사의학과에서 결핵균 으로 판명된 모든 균주를 대상으로 하였다. 결핵균은 호흡기 검체에서 검출된 경우만을 대상으로 하였으며, 동일환자에서 중복채취된 균주는 검사대상에서 제외하였다. 결핵균 동정은 상품화된 중합효소연쇄반응법(PCR)인 Amplicor Mycobacterium tuberculosis Test (Amplicor, Roche Diagnostic Systems, Inc., Branchburg, NJ, USA), AdvanSure TB/NTM real-time PCR kit (LG생명과학, 서울, 한국), Seeplex MTB/NTM ACE Detection (Seegene Inc., 서울, 한국), MTB-ID V3 assay system (M\&D, 원주, 한국), 또는 Real MTB-ID (YD Diagnostics, 용인, 한국) 를 이용하여 시행하였다.

환자의 기본정보, 과거력, 초치료와 재치료의 구분은 병력지 를 검토하여 후향적으로 조사하였으며, 가톨릭대학교 중앙의 료원 임상시험 심사위원회 심의(IRB 3104-33)를 통과하였다.

\section{2. 방법}

항결핵제 감수성 검사는 대한결핵협회 결핵연구원에 의뢰하여 Löwenstein-Jensen 고형배지를 이용한 절대농도법으로 시행하였 다. 총 15 종에 대한 항결핵제의 종류 및 판정 기준 농도는 rifampin (RFP) $40 \mu \mathrm{g} / \mathrm{mL}$, isoniazid (INH) $0.2 \mu \mathrm{g} / \mathrm{mL}$, ethambutol (EMB) $2.0 \mu \mathrm{g} / \mathrm{mL}$, rifabutin (RBT) $20 \mu \mathrm{g} / \mathrm{mL}$, streptomycin (SM) $10 \mu \mathrm{g} / \mathrm{mL}$, amikacin (AMK) $40 \mu \mathrm{g} / \mathrm{mL}$, kanamycin (KM) $40 \mu \mathrm{g} / \mathrm{mL}$, capreomycin (CPM) $40 \mu \mathrm{g} / \mathrm{mL}$, ofloxacin (OFX) 2.0 $\mu \mathrm{g} / \mathrm{mL}$, levofloxacin (LEV) $2.0 \mu \mathrm{g} / \mathrm{mL}$, moxifloxacin (MXF) 2.0 $\mu \mathrm{g} / \mathrm{mL}$, prothionamide (PTH) $40 \mu \mathrm{g} / \mathrm{mL}$, cycloserine (CS) $30 \mu \mathrm{g} / \mathrm{mL}$, para-aminosalicylic acid (PAS) $1.0 \mu \mathrm{g} / \mathrm{mL}$ 였으며, pyrazinamide (PZA)는 pyrazinamidase법을 사용하였다.

본 연구에 사용된 항결핵제는 최근 개정된 2011년도 국내 결 핵진료지침[6]에 따라 1차 약제(경구용 일차 항결핵제: RFP, $\mathrm{INH}, \mathrm{EMB}, \mathrm{PZA}, \mathrm{RBT})$ 와 2차 약제(SM, $\mathrm{AMK}, \mathrm{KM}, \mathrm{CPM}$, $\mathrm{OFX}, \mathrm{LEV}, \mathrm{MXF}, \mathrm{PTH}, \mathrm{CS}, \mathrm{PAS}$ )로 분류하였다. MDR-TB는
$\mathrm{RFP}$ 과 $\mathrm{INH}$ 에 동시 내성인 결핵으로 정의하였고, 광범위내성 결핵(extensive drug resistant tuberculosis, XDR-TB)은 WHO에 따라 MDR-TB 중에서 fluoroquinolone (FQ)계 항결핵제 약제 중 최소 한 가지와 3 가지 주사제 결핵약(AMK, $\mathrm{KM}, \mathrm{CPM})$ 최 소 한 가지에 동시에 내성을 보이는 결핵으로 정의하였다[2].

환자군은 과거에 항결핵제 치료를 받은 적이 없거나 4주 이 내의 결핵 치료를 받았다면 초치료군으로 분류하였고 4 주 이상 결핵 치료를 받은 환자의 경우 재치료군으로 분류하였다[1,2].

\section{3. 통계}

수집된 자료는 SPSS for window 11.0 (SPSS version 11.0, SPSS Inc. Chicago, IL, USA)을 사용하였다. 환자군에 따라 항 결핵제 약제내성률에 차이가 있는지를 살펴보기 위하여 Chisquare test를 이용하였고 $P$ 값이 0.05 미만인 경우를 유의한 것 으로 판단하였다.

\section{결 과}

\section{1. 대상군의 특성}

총 542 명의 환자에게서 결핵균이 분리되었으며 초치료군이 473명 $(87.3 \%)$, 재치료군이 69 명 $(12.7 \%)$ 이었다. 지역별 재치료 군의 비율은 서울 $11.4 \%$, 대전 $12.0 \%$, 부산 $12.2 \%$, 전남 $18.2 \%$ 로 차이가 없었다 $(P>0.05)$. 성별로는 남자가 $57.2 \%(310 / 542)$ 로 초치료군과 재치료군 중 각각 $56.7 \%$ (268/473)와 $60.9 \%$ (42/69)에 해당하였지만, 환자군에 따른 성별 차이는 없었다 $(P>0.05)$. 평균 나이는 53.8세(13-97세)로 초치료군은 평균 51.8세(13-97세), 재치료군은 평균 59.2세(23-92세)였다. 19세 이하의 소아청소년결핵은 전체 균주 중 $3.1 \%$ (17/542)였다. 환 자의 연령대별 재치료군 비율은 80-89세에서 가장 높았고( $22 \%$, 8/36), 19세 이하에서는 한 명도 없었다(Fig. 1). 생산가능인구인 만 15-64세(생산연령) [12]인 환자는 63.7\% (346/542)로 초치료 군의 $65.3 \%$ (309/473), 재치료군의 $53.6 \%$ (37/69)에 해당하였으 며, 생산연령에서의 재치료군 비율은 $10.7 \%$ (37/346)였다.

MDR-TB의 성별 분포는 남자가 $51.5 \%$ (17/33)로 초치료군 의 $55.5 \%$ (10/18), 재치료군의 $46.7 \%$ (7/15)를 차지하였다. MDR-TB의 평균연령은 47.8세(16-95세)였으며 생산연령에서 의 MDR-TB 비율은 7.8\% (27/346)였다. XDR-TB 3 균주 중 2 균주는 여자에서 분리되었고, 평균 61세(49-72세)였다.

\section{2. 환자군에 따른 항결핵제 내성률}

항결핵제 감수성 검사에서 한 가지 이상의 약제에 내성을 보 이는 결핵 비율은 $18.1 \%$ (98/542)였으며 초치료군에서는 $14.6 \%$ (69/473), 재치료군에서는 42.0\% (29/69)였다. 각 항결핵제별 내성률은 INH 13.7\%, RFP 7.2\%, SM 6.6\%, RBT 5.4\%, EMB $4.6 \%$, PZA 3.9\%, OFX 및 LEV 각각 $3.5 \%$, PAS 3.1\%, PTH 


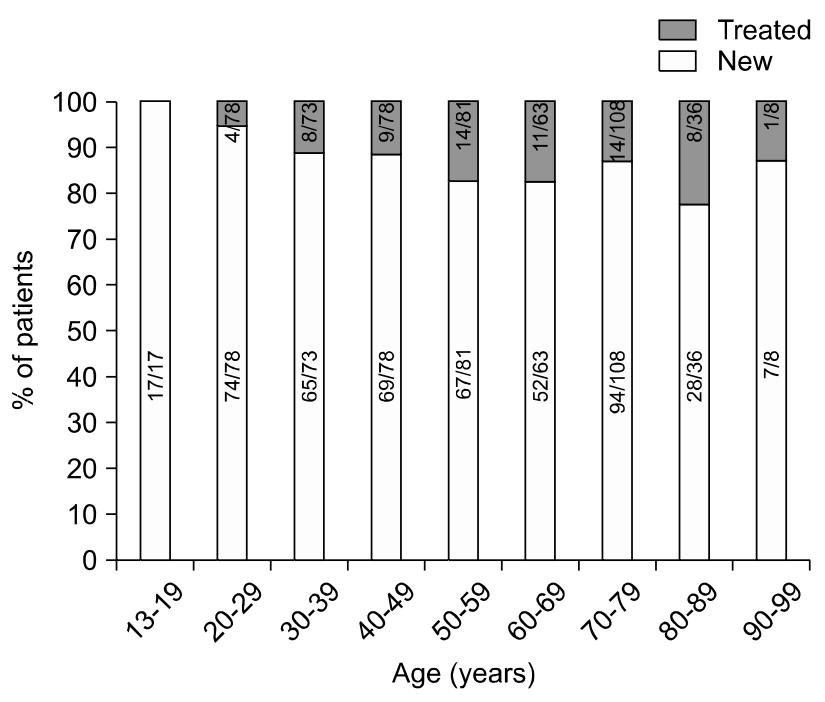

Fig. 1. Age distribution among newly and previously treated patients in this study. Abbreviations: New, newly treated patient; Treated, previously treated patient.

$2.8 \%, \mathrm{MXF} 2.6 \%$, $\mathrm{AMK}$ 및 $\mathrm{KM}$ 각각 $0.9 \%, \mathrm{CPM} 0.7 \%$, CS $0.6 \%$ 순이었고 재치료군이 초치료군에 비해 15 종 모두에 대한 항결핵제 내성률이 더 높았다 $(P<0.05)$ (Table 1). 1차 약제에 대한 내성률은 초치료군에서는 INH $(10.4 \%, 49 / 473)$ 를 제외하고 모두 5\% 미만이었지만, 재치료군에서는 INH 내성률이 $36.2 \%$ (25/69), RFP 내성률이 26.1\% (18/69)였으며 그 외의 EMB, $\mathrm{PZA}$ 및 RBT 내성률도 각각 $17.4 \%$ (12/69), $14.5 \%$ (10/69), $18.8 \%(13 / 69)$ 였다. 2차 약제에서는 SM 내성률이 가장 높았다 $(6.6 \%, 36 / 542)$ 였다. $\mathrm{AMK}, \mathrm{KM}, \mathrm{CPM}$ 내성률은 초치료군에서 는 각각 $0.2 \%$ (1/473)였지만, 재치료군에서는 4.3-5.8\%였다. $\mathrm{FQ}$ 계인 $\mathrm{OFX}, \mathrm{LEV}, \mathrm{MXF}$ 의 내성률도 초치료군에서는 각각 $1.5 \%$ (7/473), $1.5 \%$ (7/473), $1.1 \%$ (5/473)에 불과하였지만, 재 치료군에서는 각각 $17.4 \%$ (12/69), 17.4\% (12/69), 13.0\% (9/69) 로 유의하게 증가하였다 $(P<0.05)$.

$\mathrm{MDR}-\mathrm{TB}$ 는 전체 검체의 $6.1 \%$ (33/542)로 초치료군에서는 $3.8 \%$ (18/473), 재치료군에서는 21.7\% (15/69)였다. MDR-TB 중 $\mathrm{AMK}, \mathrm{KM}, \mathrm{CPM}$ 에 하나라도 내성인 경우는 $15.2 \%(5 / 33)$ 였다. $\mathrm{FQ}$ 계 중에서는 $\mathrm{OFX}$ 과 $\mathrm{LEV}$ 내성이 $39.4 \%$ (13/33)로 동 일하였고 MXF 내성이 $30.3 \%$ (10/33)였다. 특히 재치료군에서 분리된 MDR-TB 중에서 $\mathrm{AMK}, \mathrm{KM}$ 혹은 $\mathrm{CPM}$ 내성이 $26.7 \%$ (4/15)였고, $\mathrm{OFX}, \mathrm{LEV}$ 및 $\mathrm{MXF}$ 내성은 각각 $66.7 \%$ (10/15), $66.7 \%(10 / 15), 53.3 \%(8 / 15)$ 였다. XDR-TB는 전체 검체의 $0.6 \%$ (3/542)로 모두 재치료군에서만 분리되었으며, 재치료군 의 $4.3 \%$ (3/69), 재치료군에서 분리된 MDR-TB의 $20 \%(3 / 15)$ 를 차지하였다.

\section{3. 지역별 항결핵제 내성률}

1 개 이상의 약제에 대한 지역별 내성률은 부산지역이 가장 높
Table 1. Prevalence of anti-tuberculosis drug resistance in this study

\begin{tabular}{lcccr}
\hline & & \multicolumn{2}{c}{ Total no (\% of patients) } & \\
\cline { 3 - 4 } & No (\%) value & New (\%) & Treated (\%) \\
\hline Total tested & 542 & 473 & 69 \\
$\geq$ One* & $98(18.1)$ & $69(14.6)$ & $29(42.0)$ & $<0.001$ \\
Resistance to & & & & \\
RFP & $39(7.2)$ & $21(4.4)$ & $18(26.1)$ & $<0.001$ \\
INH & $74(13.7)$ & $49(10.4)$ & $25(36.2)$ & $<0.001$ \\
EMB & $25(4.6)$ & $13(2.7)$ & $12(17.4)$ & $<0.001$ \\
PZA & $21(3.9)$ & $11(2.3)$ & $10(14.5)$ & $<0.001$ \\
RBT & $29(5.4)$ & $16(3.4)$ & $13(18.8)$ & 0.002 \\
SM & $36(6.6)$ & $26(5.5)$ & $10(14.5)$ & $<0.001$ \\
AMK & $5(0.9)$ & $1(0.2)$ & $4(5.8)$ & $<0.001$ \\
KM & $5(0.9)$ & $1(0.2)$ & $4(5.8)$ & 0.002 \\
CPM & $4(0.7)$ & $1(0.2)$ & $3(4.3)$ & 0.006 \\
OFX & $19(3.5)$ & $7(1.5)$ & $12(17.4)$ & $<0.001$ \\
LEV & $19(3.5)$ & $7(1.5)$ & $12(17.4)$ & $<0.001$ \\
MXF & $14(2.6)$ & $5(1.1)$ & $9(13.0)$ & $<0.001$ \\
PTH & $15(2.8)$ & $10(2.1)$ & $5(7.2)$ & 0.010 \\
CS & $3(0.6)$ & $1(0.2)$ & $2(2.9)$ & $<0.001$ \\
PAS & $17(3.1)$ & $12(2.5)$ & $5(7.2)$ & $<0.001$ \\
MDR-TB & $33(6.1)$ & $18(3.8)$ & $15(21.7)$ & 0.001 \\
XDR-TB & $3(0.6)$ & 0 & $3(4.3)$ & 0.001 \\
\hline
\end{tabular}

*Resistant to one or more anti-tuberculosis drugs among 15 antituberculosis drugs using in this study.

Abbreviations: New, newly treated patient; Treated, previously treated patient; RFP, rifampin; INH, isoniazid; EMB, ethambutol; PZA, pyrazinamide; RBT, rifabutin; SM, streptomycin; AMK, amikacin; KM, kanamycin; CPM, capreomycin; OFX, ofloxacin; LEV, levofloxacin; MXF, moxifloxacin; PTH, prothionamide; CS, cycloserine; PAS, para-aminosalicylic acid; MDR-TB, multi-drug resistance TB including rifampin and isoniazid resistance; XDR-TB, extensively drug resistance $\mathrm{TB}$.

았고(28.9\%, 26/90), 전남 $(19.3 \%, 17 / 88)$, 서울(17.1\%, 45/264) 지 역순이었고, 대전이 가장 낮았다 $(10 \%, 10 / 100) . \mathrm{INH}$ 에 대한 지역 별 내성률도 동일 양성을 보여 부산지역이 가장 높았고 $(23.3 \%$, $21 / 90)$, 전남(13.6\%, 12/88), 서울(12.9\%, 34/264), 대전(7.0\%, 7/100)순이었다(Table 2). $\mathrm{AMK}, \mathrm{KM}$ 혹은 $\mathrm{CPM}$ 내성인 5 균주는 서울 일부 병원과 부산지역의 재치료군에서만 분리되었다. $\mathrm{FQ}$ 계 내성률도 부산지역이 가장 높았고(4.4-6.7\%) 특히 부산지역 재치 료군에서의 FQ 내성률은 $18.2-27.3 \%$ 였는데, 서울지역 일부 병원 의 재치료군에서도 $21.4-35.7 \%$ 가 FQ 내성을 보였다(Table 3).

한편, MDR-TB도 부산지역 분리율이 가장 높았는데 $(15.6 \%$, $14 / 90)$, 특히 부산지역 재치료군의 경우 분리균주의 $54.5 \%$ 가 MDR-TB였다. 그 다음은 서울 $6.1 \%$ (16/264), 전남 2.3\% (2/88) 순이었으며 대전이 $1.0 \%(1 / 100)$ 로 가장 낮았다. XDR-TB인 3 균 주는 서울 일부 병원과 부산지역의 재치료군에서만 분리되었다.

\section{고 찰}

본 연구 대상 중 초치료군은 평균 $87.3 \%$ 로 2009년 대한결핵 
Table 2. Anti-tuberculosis drug resistance rates among new and previously treated patients in six hospitals

\begin{tabular}{|c|c|c|c|c|c|c|c|c|c|}
\hline \multirow{2}{*}{ Hospital } & \multirow{2}{*}{$\begin{array}{l}\text { Type of } \\
\text { patients }\end{array}$} & \multirow{2}{*}{$\begin{array}{c}\text { Total no } \\
(\%)\end{array}$} & \multirow{2}{*}{$\geq$ One* } & \multicolumn{5}{|c|}{ Conventional drug susceptibility test ( $\%$ of patients) } & \multirow{2}{*}{$\begin{array}{c}\text { MDR-TB } \\
(\%)\end{array}$} \\
\hline & & & & RFP (\%) & $\mathrm{INH}(\%)$ & $\mathrm{EMB}(\%)$ & PZA $(\%)$ & RBT $(\%)$ & \\
\hline \multirow[t]{3}{*}{ SMC, Seoul } & Total & 74 & $18(24.3)$ & $8(10.8)$ & 14 (18.9) & $5(6.8)$ & $4(5.4)$ & $6(8.1)$ & $7(9.5)$ \\
\hline & New & $73(98.6)$ & $17(23.3)$ & $7(9.6)$ & $13(17.8)$ & $4(5.5)$ & $3(4.1)$ & $5(6.8)$ & $6(8.2)$ \\
\hline & Treated & $1(1.4)$ & $1(100)$ & $1(100)$ & $1(100)$ & $1(100)$ & $1(100)$ & $1(100)$ & $1(100)$ \\
\hline \multirow[t]{3}{*}{ CMCS, Seoul } & Total & 93 & $16(17.2)$ & $8(8.7)$ & $10(10.8)$ & $3(3.2)$ & $5(5.4)$ & $4(4.3)$ & $6(6.5)$ \\
\hline & New & $79(84.9)$ & $8(10.1)$ & $2(2.5)$ & $4(5.1)$ & 0 & $2(2.5)$ & $1(1.3)$ & $4(2.4)$ \\
\hline & Treated & $14(15.1)$ & $8(57.1)$ & $6(42.9)$ & $6(42.9)$ & $3(21.4)$ & $3(21.4)$ & $3(21.4)$ & $2(14.3)$ \\
\hline \multirow[t]{3}{*}{ EWUH, Seoul } & Total & 97 & $11(11.3)$ & $4(4.1)$ & $10(10.3)$ & $3(3.1)$ & $2(2.1)$ & $4(4.1)$ & $3(3.1)$ \\
\hline & New & $82(84.5)$ & $8(9.8)$ & $2(2.4)$ & 8 (9.8) & $2(2.4)$ & $1(1.2)$ & $1(1.2)$ & $2(2.4)$ \\
\hline & Treated & $15(15.5)$ & $3(20.0)$ & $2(13.3)$ & $2(13.3)$ & $1(6.7)$ & $1(6.7)$ & $3(20.0)$ & $1(6.7)$ \\
\hline \multirow[t]{3}{*}{ CMCD, Daejeon } & Total & 100 & $10(10.0)$ & $2(2.0)$ & $7(7.0)$ & 0 & $1(1.0)$ & $1(1.0)$ & $1(1.0)$ \\
\hline & New & $88(88.0)$ & 7 (8.0) & $1(1.1)$ & $4(4.5)$ & 0 & $1(1.1)$ & $1(1.1)$ & 0 \\
\hline & Treated & $12(12.0)$ & $3(25.0)$ & $1(8.3)$ & $3(25.0)$ & 0 & 0 & 0 & $1(8.3)$ \\
\hline \multirow[t]{3}{*}{ PNUH, Busan } & Total & 90 & 26 (28.9) & 15 (16.7) & $21(23.3)$ & $12(13.3)$ & $8(8.9)$ & $12(13.3)$ & 14 (15.6) \\
\hline & New & 79 (87.8) & 19 (24.1) & 9 (11.4) & $15(19.0)$ & 7 (8.9) & $4(5.1)$ & 8 (10.1) & $8(10.1)$ \\
\hline & Treated & $11(12.2)$ & 7 (63.6) & $6(54.5)$ & $6(54.5)$ & $5(45.5)$ & $4(36.4)$ & $4(36.4)$ & $6(54.5)$ \\
\hline \multirow[t]{3}{*}{ CNUH, Gwangju } & Total & 88 & 17 (19.3) & $2(2.3)$ & 12 (13.6) & $2(2.3)$ & $1(1.1)$ & $2(2.3)$ & $2(2.3)$ \\
\hline & New & $72(81.8)$ & 10 (13.9) & 0 & $5(6.9)$ & 0 & 0 & 0 & 0 \\
\hline & Treated & $16(18.2)$ & 7 (43.8) & $2(12.5)$ & $7(43.8)$ & $7(43.8)$ & $2(12.5)$ & $1(6.3)$ & $2(12.5)$ \\
\hline
\end{tabular}

*Resistant to one or more anti-tuberculosis drugs among 15 anti-tuberculosis drugs using in this study.

Abbreviations: New, newly treated patient; Treated, previously treated patient; RFP, rifampin; INH, isoniazid; EMB, ethambutol; PZA, pyrazinamide; RBT, rifabutin; MDR-TB, multi-drug resistance TB including rifampin and isoniazid resistance; SMC, Samsung Medical Center; CMCS, Seoul St. Mary's Hospital, The Catholic University of Korea; EWUH, Ewha Womans University Mokdong Hospital; CMCD, Daejeon St. Mary's Hospital, The Catholic University of Korea; PNUH, Pusan National University Yangsan Hospital; CNUH, Chonnam National University Hospital.

Table 3. The second-line anti-tuberculosis drugs among newly and previously treated patients in six hospitals

\begin{tabular}{|c|c|c|c|c|c|c|c|c|c|c|c|c|}
\hline \multirow{2}{*}{ Hospital } & \multirow{2}{*}{$\begin{array}{l}\text { Type of } \\
\text { patients }\end{array}$} & \multirow{2}{*}{$\begin{array}{c}\text { Total no } \\
(\%)\end{array}$} & \multicolumn{10}{|c|}{ Conventional drug susceptibility test (\% of patients) } \\
\hline & & & SM (\%) & KM (\%) & AMK (\%) & CPM (\%) & OFX (\%) & LEV (\%) & MXF (\%) & PTH (\%) & CS (\%) & PAS (\%) \\
\hline SMC, & Total & 74 & $5(6.8)$ & $1(1.4)$ & $1(1.4)$ & $1(1.4)$ & $4(5.4)$ & $4(5.4)$ & $3(4.1)$ & $2(2.7)$ & 0.0 & $5(6.8)$ \\
\hline \multirow[t]{2}{*}{ Seoul } & New & 73 (98.6) & $4(5.5)$ & 0 & 0 & 0 & $3(4.1)$ & $3(4.1)$ & $2(2.7)$ & $1(2.7)$ & 0.0 & $4(5.5)$ \\
\hline & Treated & $1(1.4)$ & $1(100)$ & $1(100)$ & $1(100)$ & $1(100)$ & $1(100)$ & $1(100)$ & $1(100)$ & $1(100)$ & $1(100)$ & $1(100)$ \\
\hline CMCS, & Total & 93 & $9(9.7)$ & $2(2.2)$ & $2(2.2)$ & $1(1.1)$ & $5(5.4)$ & $5(5.4)$ & $3(3.2)$ & $3(3.2)$ & $1(1.1)$ & $2(2.2)$ \\
\hline \multirow[t]{2}{*}{ Seoul } & New & 79 (84.9) & $5(6.3)$ & 0 & 0 & 0 & 0 & 0 & 0 & $1(1.3)$ & $1(1.3)$ & $1(1.3)$ \\
\hline & Treated & $14(15.1)$ & $4(28.6)$ & $2(14.3)$ & $2(14.3)$ & $1(7.1)$ & $5(35.7)$ & $5(35.7)$ & $3(21.4)$ & $2(14.3)$ & 0 & $1(7.1)$ \\
\hline EWUH, & Total & 97 & $2(2.1)$ & 0 & 0 & 0 & $1(1.0)$ & $1(1.0)$ & 0 & $1(1.0)$ & 0 & $1(1.0)$ \\
\hline \multirow[t]{2}{*}{ Seoul } & New & $82(84.5)$ & $1(1.2)$ & 0 & 0 & 0 & 0 & 0 & 0 & 0 & 0 & 0 \\
\hline & Treated & 15 (15.5) & $1(6.7)$ & 0 & 0 & 0 & $1(6.7)$ & $1(6.7)$ & 0 & $1(6.7)$ & 0 & $1(6.7)$ \\
\hline CMCD, & Total & 100 & $4(4.0)$ & 0 & 0 & 0 & 0 & 0 & 0 & 0 & 0 & $1(1.0)$ \\
\hline \multirow[t]{2}{*}{ Daejeon } & New & 88 (88.0) & $4(4.5)$ & 0 & 0 & 0 & 0 & 0 & 0 & 0 & 0 & $1(1.1)$ \\
\hline & Treated & $12(12.0)$ & 0 & 0 & 0 & 0 & 0 & 0 & 0 & 0 & 0 & 0 \\
\hline PNUH, & Total & 90 & $8(8.9)$ & $2(2.2)$ & $2(2.2)$ & $2(2.2)$ & $6(6.7)$ & $6(6.7)$ & $4(4.4)$ & $9(10.0)$ & $1(1.1)$ & $7(7.8)$ \\
\hline \multirow[t]{2}{*}{ Busan } & New & 79 (87.8) & $6(7.6)$ & $1(1.3)$ & $1(1.3)$ & $1(1.3)$ & $3(3.8)$ & $3(3.8)$ & $2(2.5)$ & $7(8.9)$ & 0 & $6(7.6)$ \\
\hline & Treated & $11(12.2)$ & $2(18.2)$ & $1(9.1)$ & $1(9.1)$ & $1(9.1)$ & $3(27.3)$ & $3(27.3)$ & $2(18.2)$ & $2(18.2)$ & $1(9.1)$ & $1(9.1)$ \\
\hline CNUH, & Total & 88 & $9(9.1)$ & 0 & 0 & 0 & $3(3.4)$ & $3(3.4)$ & $4(4.5)$ & 0 & $1(1.1)$ & $1(1.1)$ \\
\hline \multirow[t]{2}{*}{ Gwangju } & New & $72(81.8)$ & $7(8.3)$ & 0 & 0 & 0 & $1(1.4)$ & $1(1.4)$ & $1(1.4)$ & 0 & 0 & 0 \\
\hline & Treated & $16(18.2)$ & $2(12.5)$ & 0 & 0 & 0 & $2(12.5)$ & $2(12.5)$ & $3(18.8)$ & 0 & $1(6.3)$ & $1(6.3)$ \\
\hline
\end{tabular}

Abbreviations: New, newly treated patient; Treated, previously treated patient; SM, streptomycin; KM, kanamycin; AMK, amikacin; CPM, capreomycin; OFX, ofloxacin; LEV, levofloxacin; MXF, moxifloxacin; PTH, prothionamide; CS, cycloserine; PAS, para-aminosalicylic acid; SMC, Samsung Medical Center; CMCS, Seoul St. Mary's Hospital, The Catholic University of Korea; EWUH, Ewha Womans University Mokdong Hospital; CMCD, Daejeon St. Mary's Hospital, The Catholic University of Korea; PNUH, Pusan National University Yangsan Hospital; CNUH, Chonnam National University Hospital. 
협회가 발표한 초치료 환자 비율인 80.8\%나 2002-2003년 부산, 경남지역 대학병원에서의 $72.3 \%$ 보다 높았다[2,7]. 이는 기존 연구들이 일단 주치의로부터 항결핵제 감수성 검사가 의뢰된 검체만을 대상으로 약제감수성 검사를 시행하였기 때문에[6-9] 일부 초치료군의 경우 항결핵제 감수성 검사가 누락되어 상대 적으로 초치료군 비율이 낮게 보고되었을 가능성이 있었을 것 으로 생각되었다. 실제 2002-2003년 부산 경남지역 5개 대학병 원(부산대학교병원, 고신대학교 복음병원, 인제대학교 부산백 병원, 경상대학교병원, 울산대학교병원)을 대상으로 한 연구에 서도 총 결핵균 배양 양성 환자 중 평균 $27.7 \%$ (17.2-52.4\%)에 서만 항결핵제 감수성 검사가 의뢰됨을 보고하면서 전체 결핵 배양 양성환자 일부에서만 항결핵제 감수성 검사가 의뢰되는 실정임을 지적한 바 있다[7]. 최근 전 세계적으로도 초치료 환 자의 초회 약제내성이 점차 증가하고 있는 추세로[2,3], 본 연 구에서도 국내 초치료군의 $10.4 \%$ 가 실제 INH 내성이었다. 따 라서 결핵의 효율적인 관리와 치료를 위해서는 배양 양성환자 에서 분리된 첫 결핵균에 대해 항결핵제 감수성 검사를 반드시 시행하는 것이 필요하다.

본 연구에서 19세 이하의 소아청소년결핵은 전체 균주의 $3.1 \%$ 로, 기존의 대한결핵협회에서 국내 총 결핵신고환자를 대 상으로 보고한 7\%보다는 낮았다[13]. 그러나, 최근 소아청소년 기의 결핵유병률이 다시 증가하고 있는 추세 [2,12]를 고려해 보 면, 본 연구는 대상기간 및 표본 수 부족에 대한 한계점이 있고, 특히 소아결핵은 배양 검사에서 양성이 나오는 경우가 많지 않 음[12]을 감안할 때 본 연구가 결핵균배양양성 검체만을 대상 으로 수집한 것에서 오는 차이일 가능성이 있다. 한편, 결핵환 자 중 생산연령층이 차지하는 비율이 $50 \%$ 이상이면서 생산연 령층 결핵의 $7.8 \%$ 가 MDR-TB이므로 사회, 경제적 측면에서 결핵의 확산 방지를 위한 보다 적극적인 관리 방안이 필요하다 고 생각한다.

과거 결핵 치료력에 따라 항결핵제 내성률이 현저한 차이를 보이기 때문에[8] 초치료군과 재치료군으로 나누어서 항결핵 제 감수성 검사 결과를 분석하는 것이 결핵의 치료뿐만 아니라 역학적인 측면에서 매우 중요하다. 본 연구에서도 한 가지 이 상의 약제내성률이 $18.1 \%$ 였지만 초치료와 재치료군으로 나누 어 보면 각각 $14.6 \%$ 와 $42 \%$ 로 큰 차이를 보였다 $(P<0.05)$. 항결 핵제별로 보면 1차 항결핵제의 내성률은 초치료군 경우 $\mathrm{INH}$ (10.4\%)를 제외하고는 모두 5\% 미만이었던 반면, 재치료군의 RFP, INH 내성률은 $26.1 \%$ 와 $36.2 \%$ 로 초치료군보다 각각 5.9 배, 3.5배 높았고 EMB, PZA, RBT 내성률도 14.5-18.5\%로 초 치료군보다 5.5-6.4배 더 높았다. 한편, 2차 항결핵제는 그 나라 에서의 내성 패턴에 따라 국가에서 표준처방을 정하기도 하고 각 환자마다 과거 치료력과 그 지역의 내성 패턴을 고려하여 경험적으로 처방하거나 과거 치료력과 각 환자의 내성 결과에 따라 치료 처방을 결정할 수 있다[2,3,14]. 일반적으로 $\mathrm{FQ}$ 계와
Aminoglycoside계 항생제는 가장 보편적으로 사용되는 2차 항 결핵제이다. 특히 $\mathrm{FQ}$ 는 2 차 항결핵제 중 중요한 약제로 MDR$\mathrm{TB}$ 치료에 필수적이며 이들 약제들에 대한 내성 여부가 질병 의 예후를 결정하는 중요한 요소가 되는데[2,15], 세 종류 $\mathrm{FQ}$ (OFX, LEV, MOX) 중에는 MXF가 항균력이 가장 강하고 그 다음은 LEV이며 OFX이 항균력이 가장 약하다[6]. 본 연구에 서도 $\mathrm{OFX}$ 과 $\mathrm{LEV}$ 내성률은 각각 $3.5 \%$ 인데 비해 MXF 내성률 은 2.6\%였다. 특히 $\mathrm{FQ}$ 계 항결핵제는 재치료군 간의 약제내성 률이 초치료군에 비해 10 배 이상 높을 정도로 매우 차이가 크 다(각각 1.1-1.5\%와 $13.0-17.4 \%, P<0.05)$. 따라서 재치료환자 가 이 약을 2 차 항결핵제로 선택 시 항결핵제 감수성 검사의 결과 확인이 필수적이며 전통적인 약제감수성 검사는 시간이 많이 소요되므로 분자생물학적 방법을 이용한 신속내성검사의 도입도 고려해야 할 것으로 생각한다.

본 연구의 MDR-TB 비율은 $6.1 \%$ 로 초치료군에서는 $3.8 \%$, 재치료군에서는 $21.7 \%$ 였다. 이는 세계 74 개 지역의 MDR-TB 초치료군 평균인 $1.1 \%$ 이나 일본의 $0.7 \%$ 보다 높은 수치로 중 국, 인도, 베트남 등과 유사하였다[2,4,10,11]. 그러나 기존의 $\mathrm{WHO}$ 에서 보고한 2004년도 결과(초치료군의 $2.7 \%$, 재치료군 의 $14.0 \%$ )나 2009 년 대한결핵협회의 보고(보건소 신환의 $2.8 \%$, 재치료군의 $8.5 \%$ )보다 높았다[2,3,12], 이는 본 연구가 대학병 원에서 자료를 수집한 데서 오는 차이일 수도 있지만, 항결핵 제 감수성 검사 의뢰 과정에서 주치의에 따라 누락될 수 있었 던 일부 재치료군의 항결핵제 내성률이 실제 반영된 결과일 가 능성도 있으며 또한 시기적으로 보면 시간이 지날수록 MDR$\mathrm{TB}$ 가 점차 증가하고 있는 것을 반영하여 주는 것으로 생각한 다. 2 차 항결핵제에 대해서도 MDR-TB 중 $30 \%$ 이상이 $\mathrm{FQ}$ 내 성이었고, $\mathrm{AMK}, \mathrm{KM}$, 혹은 $\mathrm{CPM}$ 에 내성인 균주도 $15.2 \%$ 였다. 특히 재치료 환자에서 분리된 MDR-TB의 $\mathrm{FQ}$ 내성률이 $50 \%$ 를 넘고, $\mathrm{AMK}, \mathrm{KM}, \mathrm{CPM}$ 에 하나라도 내성인 것도 $26.7 \%$ 인 바, 이 약들을 2차 약제로 선택 시 이미 내성이 생긴 약제를 처방 하지 않도록 항결핵제 감수성 검사의 결과확인이 필수적이며 2차 항결핵제에 대해서도 분자생물학적 방법을 이용한 신속내 성검사법의 도입을 고려해야 할 것으로 생각한다.

XDR-TB는 부적절한 항결핵 약물치료를 받은 환자에서 약제 내성균이 선택적으로 증식하여 발생하기도 하지만(획득내성), XDR-TB 환자에서 나온 XDR-TB균이 다른 사람에게 전파되어 발생할 수 있다(초회내성) [2]. 본 연구에서는 전체 균주의 $0.6 \%$ 로 기존의 0.15-1.4\% 보고[2,7-9,11]와 유사하였으며 모두 재치 료군에서 분리되어 모두 획득내성으로 생각되었다. MDR-TB에 서의 XDR-TB 비율은 9.1\% (3/33)로 2006년 미국 CDC 조사의 $15.4 \%$ [14]보다 낮았다. 미국 $\mathrm{CDC}$ 연구에서는 MDR-TB이면서 6 가지 계열의 2차 항결핵제들(AG, polypeptide, $\mathrm{FQ}$, prothioamide/ethionamide, CS, PAS) 중 3 가지 이상에 동시에 내성인 경 우를 XDR-TB로 정의[14]하였으나 본 연구에서는 2006년 개정 
된 $\mathrm{WHO}$ 의 기준[2]을 따르고 있어 XDR-TB 비율이 감소된 것 으로 생각한다. 그러나 재치료군에서는 MDR-TB 중 20\% (3/15) 가 XDR-TB이므로 재치료 환자는 RFP, INH 내성 여부를 신속 히 판독하여 MDR-TB를 진단하는 것이 결핵의 치료뿐만 아니 라 XDR-TB의 전파 방지에도 매우 유용할 것으로 생각한다.

지역별로는 부산지역의 항결핵제 내성률 및 MDR-TB 비율 이 가장 높았고, 대전지역이 가장 낮았다. 특히, 부산 지역 재치 료군 54.5\%가 MDR-TB였는데, 이는 기존 2002-2003년도 부산, 경남 지역 보고인 44\%보다 높았지만[7], Kim 등[10]이 20002004년에 보고한 영남지역의 MDR-TB 비율(59.6\%)과는 일치 하였다. 그러나 본 연구가 서울을 제외하고는 한 지역 당 1 개 병원만을 대상으로 하였으므로 MDR-TB 정확한 실태 파악을 위해 전국 규모의 다수의 병원 및 검사기관을 포함하는 추후 연구가 필요할 것으로 생각한다.

결론적으로 MDR-TB 및 XDR-TB 빈도가 재치료군에서 크 게 높아지므로 결핵환자의 초회 치료가 성공할 수 있도록 관리 하는 것이 필요할 것으로 생각한다. 또한, $\mathrm{FQ}$ 계는 초치료와 재 치료군 간에 약제내성률의 차이가 매우 크면서(각각 1.1-1.5\% 와 $13.0-17.4 \%, P<0.05)$, 특히 재치료군에서 분리한 MDR- TB 의 53.3-66.7\%가 FQ 내성이었다. 따라서 이 약을 2차 항결핵제 로 선택 시 재치료환자는 항결핵제 감수성 검사의 결과 확인이 필수적이며 더불어 내성여부를 신속하게 진단하기 위하여 분 자생물학적 방법을 이용한 신속내성검사의 도입도 고려해야 할 것으로 생각한다. 지역별로는 부산지역의 항결핵제 내성률 및 MDR-TB가 가장 높았으나, 본 연구가 서울을 제외한 곳은 지역당 1 개 병원만을 대상으로 하였으므로 추후 전국 규모의 다수의 병원들을 포함하는 연구가 필요할 것으로 생각한다.

\section{감사의 글}

본 연구는 2010년도 임상미생물학회-LG 생명과학(주)의 연구 비 지원을 받아 수행되었음.

\section{참 고 문 헌}

1. Espinal MA, Laszlo A, Simonsen L, Boulahbal F, Kim SJ, Reniero
A, et al. Global trends in resistance to antituberculosis drugs. World Health Organization-International union against tuberculosis and lung disease working group on anti-tuberculosis drug resistance surveillance. N Engl J Med 2001;344:1294-303.

2. World Health Organization. ed. Guidelines for the Programmatic Management of Drug Resistant Tuberculosis: Emergency Update 2008. Geneva, Switzerland; World Health Organization, 2008.

3. Korea Centers for Disease Control and Prevention. ed. Annual Report on the Notified Tuberculosis Patients in Korea 2009. Seoul; Korea Centers for Disease Control and Prevention, 2010.

4. Wright A, Zignol M, Van Deun A, Falzon D, Gerdes SR, Feldman $\mathrm{K}$, et al; Global Project on Anti-Tuberculosis Drug Resistance Surveillance. Epidemiology of antituberculosis drug resistance 2002-07: an updated analysis of the Global Project on Anti-Tuberculosis Drug Resistance Surveillance. Lancet 2009;373:1861-73.

5. Bloch AB, Cauthen GM, Onorato IM, Dansbury KG, Kelly GD, Driver CR, et al. Nationwide survey of drug-resistant tuberculosis in the United States. JAMA 1994;271:665-71.

6. Joint Committee for the Development of Korean Guidelines for Tuberculosis. ed. Korean Guidelines for Tuberculosis. 1st ed. Seoul; Korea Centers for Disease Control and Prevention, 2011:34-6.

7. Jeong SH, Lee DD, Choi JC, Kim S, Shin JH, Jeong J, et al. Multi-center study on cost effectiveness of anti-tuberculosis drug susceptibility test. Infect Chemother 2005;37:16-21.

8. Kim SJ, Bai GH, Hong YP. Drug-resistant tuberculosis in Korea, 1994. Int J Tuberc Lung Dis 1997;1:302-8.

9. Bai GH, Park YK, Choi YW, Bai JI, Kim HJ, Chang CL, et al. Trend of anti-tuberculosis drug resistance in Korea, 1994-2004. Int J Tuberc Lung Dis 2007;11:571-6.

10. Kim BJ, Lee IH, Lee DH, Bai GH, Kong SJ, Lee SH, et al. The current status of multidrug-resistant tuberculosis in Korea. Tuberc Respir Dis 2006;60:404-11.

11. Chol CJ, Lim SY, Suh GY, Chung MP, Kim H, Kwon OJ, et al. Drug resistance rates of Mycobacterium tuberculosis at a private referral center in Korea. J Korean Med Sci 2007;22:677-81.

12. KOSIS. Population of working age (15 to 64) by sex and age group. Korean Statistical Information Service Web Site on On-line Publication. http://kosis.kr/wnsearch/totalSearch.jsp/ [Online] (last visited on 11 September 2012).

13. Lee SJ, Ahn YM, Kim HJ. Drug resistance of Mycobacterium tuberculosis in children. Korean J Pediatr 2009;52:61-7.

14. Centers for Disease Control and Prevention (CDC). Emergence of Mycobacterium tuberculosis with extensive resistance to secondline drugs-worldwide, 2000-2004. MMWR Morb Mortal Wkly Rep 2006;55:301-5.

15. Crofton J, Chaulet P, Maher D. Guidelines for the Management of Drug-resistant Tuberculosis. Geneva; World Health Organization, 1997. 
$=$ 국문초록=

\section{호흡기 검체에서 분리된 결핵균의 항결핵제 내성 실태: 국내 다기관 연구}

${ }^{1}$ 가톨릭대학교 의과대학 진단검사의학교실, ${ }^{2}$ 성균관대학교 삼성서울병원 진단검사의학과,

${ }^{3}$ 양산부산대학교병원 진단검사의학과, ${ }^{4}$ 이화여자대학교 목동병원 진단검사의학과, ${ }^{5}$ 전남대학교병원 진단검사의학과

\section{김자영 ${ }^{1}$, 박연준 $^{1}$, 이남용 $^{2}$, 장철훈 $^{3}$, 이미애 ${ }^{4}$, 신종희 $^{5}$}

배경: 호흡기 검체에서 검출된 모든 결핵균을 대상으로 초치료와 재치료 환자군으로 나누어 총 15 종의 항결핵제 내성률 을 조사하였다.

방법: 2010년 2월에서 7월 사이에 전국에 분포한 국내 6개 대학병원의 호흡기 검체에서 검출된 모든 결핵균을 대상으로 하였다. 과거 치료력에 따라 초치료군과 재치료군으로 나누어 항결핵제 내성률을 조사하고 지역별로 내성양상을 비교해 보았다.

결과: 총 542명의 환자 중 초치료군이 473명(87.3\%), 재치료군이 69명(12.7\%)이었다. 초치료군과 재치료군 간에 다제내성 결핵, fluoroquinolone 계(ofloxacin, levofloxacin, and moxifloxacin) 내성률 및 광범위내성결핵 비율은 초치료군에서는 각각 $3.8 \%, 1.1-1.5 \%$ 및 $0 \%$ 였고 재치료군에서는 각각 $21.7 \%, 13.0-17.4 \%$ 및 $4.3 \%$ 였다. 재치료군에서 분리된 다제내성결핵 중 $20 \%$ (3/15)가 광범위내성결핵이었다. 항결핵제 내성률은 지역적 분포에 따라 다양하였다.

결론: 다제내성결핵 및 광범위내성결핵의 빈도가 재치료군에서 크게 높아지므로 결핵 환자의 초회 치료가 성공할 수 있도록 관리하는 것이 필요할 것으로 생각한다. 더불어, 재치료군에서는 항결핵제를 선택하기 전에, fluoroquinolone을 포함한 항결핵제 감수성 검사의 결과확인이 필수적이다. [Ann Clin Microbiol 2013;16:1-7]

교신저자 : 박연준, 137-701, 서울시 서초구 반포동 505

가톨릭대학교 서울성모병원 진단검사의학과

Tel: 02-2258-1640, Fax: 02-2258-1719

E-mail: yjpk@catholic.ac.kr 